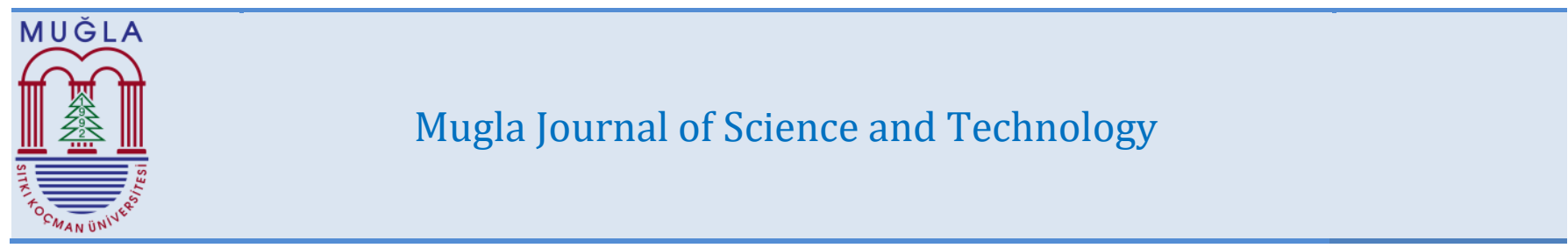

\title{
ECONOMIC ANALYSIS OF REQUIRED HEAT ENERGY FOR A RESIDENCE BY USING CONDENSING AND CONVENTIONAL COMBI BOILER
}

\author{
Muhammed Arslan OMAR ${ }^{1 *}$, Kemal ALTINIŞIK ${ }^{2}$, Ahmet Ali SERTKAYA ${ }^{3}$, Nesrin ADIGÜZEL ${ }^{1}$
}

${ }^{1}$ Department of Mechanical Engineering, Engineering and Architecture Faculty, Kafkas University , 36000, Kars, Turkey m.arslanomar@gmail,nesrin_ozdemir25@yahoo.com

${ }^{2}$ Department of Mechanical Engineering, Engineering Faculty, Selçuk University, 42030, Konya, Turkey kaltinisik@selcuk.edu.tr

3Department of Mechanical Engineering, Seydişehir A. Cengiz Engineering Fac., Konya N. Erbakan University, 42030, Konya, Turkey asertkaya@konya.edu.tr

Received: 30.10.2015, Accepted: 11.12.2015

*Corresponding author

\section{Abstract}

In this study, a comparison and economic analysis of energy required for heating and hot water by condensing and conventional combi for a family was performed. After determining the energy for the family the cost of consumption energy calculated which was supplied by each two types of combi. It was determined that using of condensing combi will provide the average 15,6\% energy savings to family. Furthermore, the average $40 \%$ impairment of the exhaust gas temperature of condensing combi than conventional combi causes the reduction of emissions rate and decrease the global warming. Reduction of emissions is extremely important in terms of air pollution. Compared to a conventional combi the initial investment of a condensing combi is high, but due to usage of latent heat of water vapor in the exhaust gas the payback period is short, and therefore the cost difference could be ignored. This study emphasizes that, usage of the condensing combies which are compulsory in European Union countries, will contribute the family budgets and national economy.

Keywords: Condensing combi, Conventional combi, Energy saving

\section{BİR KONUTUN ISI ENERJISİ İHTIYACININ YOĞUŞMALI VE KONVANSIYYONEL KOMBİ KULLANILARAK KARȘILANMASININ EKONOMIK ANALIZİ}

\section{Özet}

Bu çalışmada, 4 kişilik bir ailenin yoğuşmalı ve konvansiyonel kombi kullanarak ısı enerjisi ve sıcak su ihtiyacının bir karşılaştırılması ve ekonomik analizi yapıldı. Değerlendirmede ailenin ısınma ve sıcak su ihtiyacı için ısı enerjisi belirlenerek bu enerjinin her iki tip kombi ile karşılandığında ortaya çıkan enerji maliyeti hesaplandı. Yoğușmalı kombi kullanımının aileye ortalama \%15,6 enerji tasarrufu sağlayacağı belirlendi. Ayrıca egzoz gazı sıcaklğının konvansiyonel kombilere göre ortalama \%40 oranında düşük olmasl, küresel ısınmanın azalmasına ve emisyon değerlerinin düssmesine neden olmaktadır. Yoğușmalı bir kombinin ilk yatırım maliyetinin konvansiyonel bir kombiye göre yüksek olmasına karșın, egzoz gazındaki su buharının gizli ısısından yararlanılması nedeniyle, geri ödeme periyodunun kısa olması ilk yatırım maliyetindeki farkın göz ardı edilebileceğini gösterdi. Bireysel anlamda aile bütçesine ve ulusal bazda ülke ekonomisine katkı sağlayacağı için, Avrupa Birliği ülkelerinde kullanımı zorunlu olan yoğuşmalı kombilerin daha avantajlı olduğu, bu çalıșmada gösterildi.

Anahtar Kelimeler: Yoğuşmalı kombi, Konvansiyonel kombi, Enerji tasarrufu

\section{Introduction}

Fossil energy use in line with the increasing environmental pollution; the greenhouse effect caused by the exhaust gases in the atmosphere leads to global warming and breaking the ecological balances in the nature. The world population means $100 \%$ increase in global energy use has increased 4 -fold after 1945; consequently the world's primary energy needs continue to increase, as shown in Figure 1 [1]. This increase in energy use, led to an increase of harmful emissions and the greenhouse effect and CO2 content in the atmosphere in 1958, $315 \mathrm{ppm} / \mathrm{m} 3$ in 2004, while $379 \mathrm{ppm} / \mathrm{m} 3$ reached. This is two times more effective than other $\mathrm{CO} 2$ emissions increase global warming by the greenhouse effect is produced in the power generation sector. The developed countries are responsible for $76 \%$ of $\mathrm{CO} 2$ emissions occur in 1850-2002 years [2]. In Figure 2 the increasing of $\mathrm{CO} 2$ emissions by years is shown [3]. Consisting origin fossil used for energy production by combustion of fuel $\mathrm{NOx}, \mathrm{CO}$ and emissions such as $\mathrm{CO} 2$, fuel type, the combustion process participating in the air-fuel ratio and the combustion can be controlled depending on the use of efficient technology. Serious and planned investments are carrying out in the world for efficient energy usage. The one third of energy investments in efficiency are related to energy consumption in housing industry process. The investment for energy efficiency in residential and services sector is shown in Figure 3; and the investments for heating-cooling; insulation for energy-efficient equipment and lighting space is shown Figure 4 [4]. 


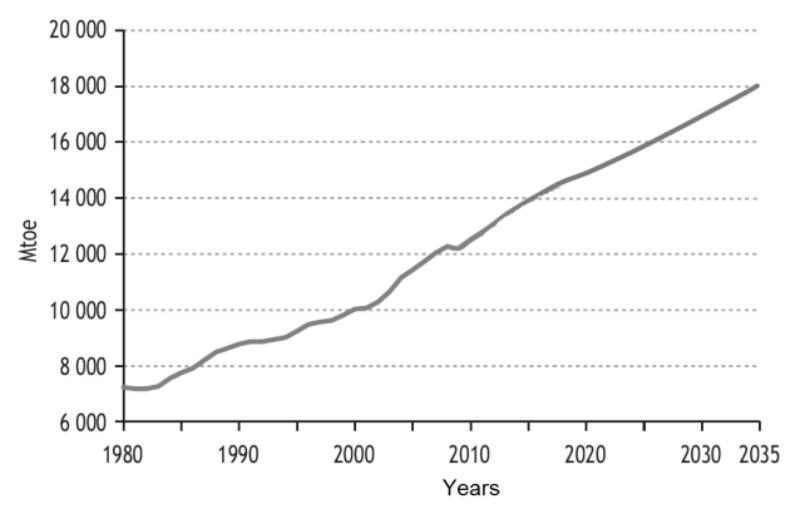

Figure 1. World primary energy consumption

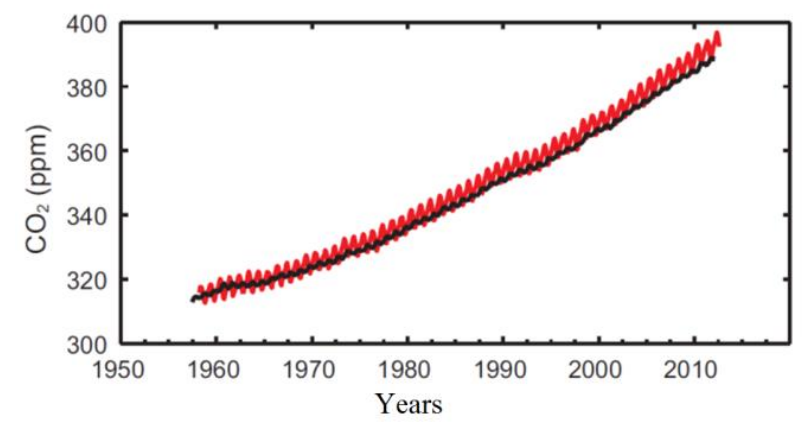

Figure 2. Increasing of $\mathrm{CO} 2$ by years

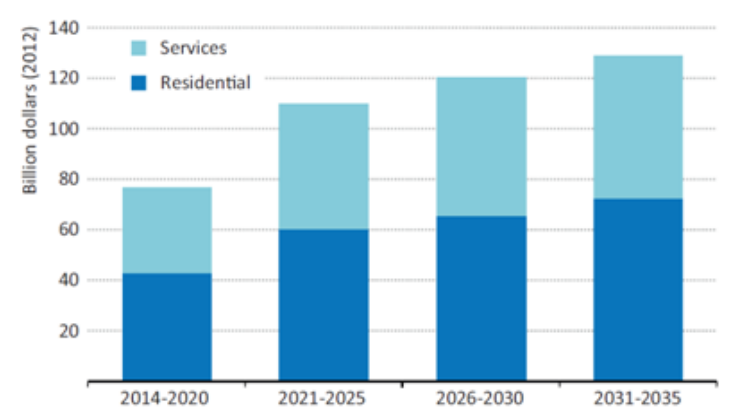

Figure 3. Average annual investment in energy efficiency in buildings in the new policies scenario

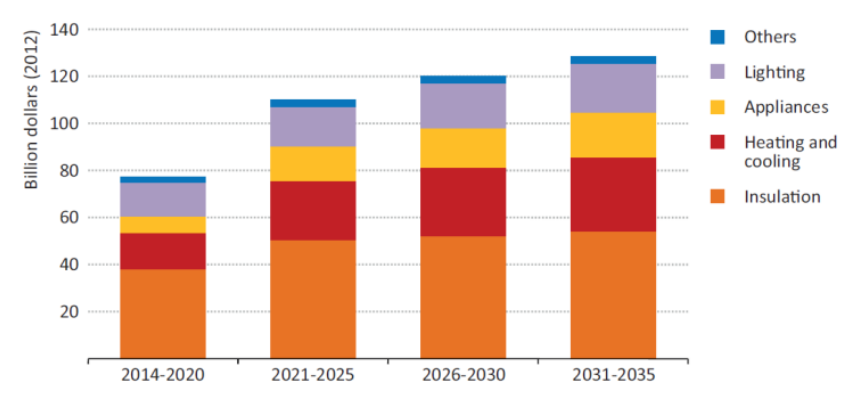

Figure 4. Average annual investment in energy efficiency in buildings by end-use in the new policies scenario

The direction of a tendency to enter the growing demand for energy costs purifiers; efficient, it has led to a compact and environmentally sensitive device. This requirement, fuel economy and low exhaust gas emissions of large increases in the amount boilers and boiler used in Turkey with condensation technology that satisfies the demand for workers combi boiler to the emergence of the system and is why it is preferred as shown in Table 1 were observed [5]. Given combi condensing boilers used in Turkey constitutes only $10 \%$ of the total boiler.

Table 1 . The quantity of combies and boilers which used in Turkey between 2005-2010 [5]

\begin{tabular}{llllllll} 
Years & 2005 & 2006 & 2007 & 2008 & 2009 & 2010 \\
\hline Combi & 549000 & 684120 & 595510 & 644000 & 665385 & 754996 \\
& & & & & & \\
Boiler & 6058 & 5712 & 7486 & 7079 & 5543 & 14130 \\
\hline
\end{tabular}

\subsection{Condensing Boiler Technology}

Boilers are devices that meet the needs of individual residential heating and hot water. According to the technical details; vented boilers, hermetic boilers are classified as semi-hermetic boilers and condensing boilers. Combi boilers usage earned popularity in Turkey in a short time after 1989 because of advantages such as environmentally; lower emission; independently usage in each apartment and ability to meet the hot water and heating needs with a single device.

Condensation energy technology objectives through the utilization of heat from flue secret emerged thrown out by preventing condensation forming is to reduce fuel consumption and harmful emissions. While in conventional boiler flue gas temperature of $135-150{ }^{\circ} \mathrm{C}$ condensing boilers in waste gas temperature is lowered to $55{ }^{\circ} \mathrm{C}$ [6]. $80-95^{\circ} \mathrm{C}$ difference between the waste gas temperatures is reflected in the difference in yield.

Natural gas (CH4) and hydrogen molecules in the compound is burned in oxygen molecules supplied to the combustion air combine with water (H2O) are the molecules. Depending on the combustion conditions comprising 1.5 to $1.7 \mathrm{~kg}$ amount of water is evaporated by absorbing heat from the environment and are taken out along with the flue gas. Heat taken by the water vapor in the flue gas condensation technology of condensing combustion chamber again recuperates. Because it has a corrosive effect caused by condensation water, boiler and boiler using this technology is used special materials such as stainless steel.

Natural gas condensate with the resulting yield increase is up to $111 \%$ based on lower heating value as a theoretical value for the boiler [2]. Amount of heat obtained in this technology depends on the installation return water temperature. Return water temperature no matter how the same amount of water vapor condensing and condensing water vapor is more latent heat is revealed in parallel to the amount [7].

Premix burner technology used in condensing boilers unlike burners used in conventional boilers can operate with high efficiency in a wide modulation range. The air required for combustion, providing variable speed fan with the air and fuel before coming to the front burner homogenized the mixtures prepared with the diffuser ideal combustion conditions are provided. Instant energy demand and consequently the air-fuel ratio determined by the electronic brain condensing boilers, optimal fan speed is adjusted. Burning for air pressure depending on the controlled gas valve combustion to provide the amount of fuel needed, combine optimum combustion with 
controlled air-fuel ratio with the electronic system is achieved low emissions with performing high combustion efficiency. Premix burners used air-fuel prepared by the method has a quiet operation with short flame length. Condensing boiler in combustion burner used in creating large agglomerations and preventing surface temperature harmful emissions in the waste gas formed at high temperatures. According to the employees need instant heat in a wide modulation range of yield losses to occur in this type of burner stand-up problems and high emissions have been avoided.

Conventional boilers required for combustion gas flow in fixed speed fans are used to vary the airflow is reduced efficiency due to the high excess air coefficient composed remained constant. In the absence of the boiler efficiency condensing technology is around $85-90 \%$. Constant speed fans used in conventional boilers is caused by the high temperature of the exhaust gas. The boiler combustion chamber to fixed speed fan to blow the same amount of air at low temperatures, more oxygen needed for combustion is thrown out with the heat drawn from the environment. If less oxygen is required to burn the combustion lacking. Increase the amount of $\mathrm{CO}$ is formed by the incomplete combustion of waste gases, air pollution and leads to yield losses.

\section{Material and Method}

$31 \%$ of the energy for heating the portion produced in Turkey and $12-15 \%$ of this energy is spent to produce hot water [8].
Large parts of the energy used in homes are generally obtained from the boiler. Combi boilers and compared to the amount produced and sold in Turkey, the rate of increase in the rate of increase in the use of combined sales gains appear to be more than [5].

In this study, clear area $100 \mathrm{~m} 2$ with a mezzanine floor apartment of heat loss calculations for the Kars province has been calculated by monthly average outdoor temperature of Kars. The apartment is located in the northern and western side, hall, living room, bedroom, children's room, kitchen and bathroom for heat loss calculation was considered. Polyurethane foam insulation material extruded (XPS) and 5 $\mathrm{cm}$ on the outside walls with external, independent interdepartmental and inter-floor use is made of $3 \mathrm{~cm}$ acceptance. Heat losses for parts of building in winter months are calculated [9] and it is given in Table 2.

$$
\begin{gathered}
Q=q_{i}+q_{s} \\
q_{i}=q_{o}\left(1+\% Z_{D}+\% Z_{H}\right) \\
q_{o}=k A \Delta T \\
q_{s}=\Sigma(a l) R H \Delta T Z_{e}
\end{gathered}
$$

Table 2. The heat looses of rooms

\begin{tabular}{|c|c|c|c|c|c|c|}
\hline \multirow{2}{*}{ Rooms } & \multicolumn{6}{|c|}{ Calculated heat lose (W) } \\
\cline { 2 - 7 } & November & December & January & February & March & April \\
\hline Salon & 759 & 958 & 1165 & 1269 & 1223 & 1035 \\
\hline Living room & 355 & 433 & 514 & 555 & 537 & 463 \\
\hline Children room & 1007 & 1061 & 1117 & 1145 & 1132 & 1082 \\
\hline Bedroom & 429 & 559 & 694 & 762 & 732 & 610 \\
\hline Kitchen & 407 & 559 & 718 & 797 & 762 & 619 \\
\hline Bath & 737 & 737 & 737 & 737 & 737 & 737 \\
\hline Total & 2580 & 2915 & 3266 & 3441 & 3363 & 3047 \\
\hline
\end{tabular}

The average daily hot water needs for a family of four 220 liter/day considering adoption and Kars provinces spouse of mains water temperature by months. Equation (5) and (5a) for preparing hot water for heat energy required for 12 months.

$$
\begin{gathered}
Q=m c_{p} \Delta T \\
Q=m c_{p}\left(T_{o}+T_{i}\right)
\end{gathered}
$$

The amount of energy required for heating and hot water preparation by months are given in Table 3. The average monthly temperature of Kars according to the basis month to cover the heat loss calculation and the total energy requirements of the circle calculated hot water energy needs of catalog value used in conventional and condensing boilers fuel consumption and comparison in terms of initial investment costs are shown in Table 4. Costs were calculated on the basis of the current boiler and natural gas prices. 
Table 3. Energy consumption of residence per months

\begin{tabular}{|c|c|c|c|}
\hline Months & $\begin{array}{c}\text { Tempera } \\
\text { ture of } \\
\text { water } \\
\left({ }^{\circ} \mathrm{C}\right)\end{array}$ & $\begin{array}{c}\text { Heating load } \\
\text { (W/month) }\end{array}$ & $\begin{array}{c}\text { Hot water } \\
\text { load } \\
\text { (W/month) }\end{array}$ \\
\hline January & 3 & $\begin{array}{c}3.679 .060,0 \\
8\end{array}$ & $513.379,08$ \\
\hline February & 1,4 & $\begin{array}{c}3.537 .703,5 \\
7\end{array}$ & $435.555,32$ \\
\hline March & 1,2 & $\begin{array}{c}3.811 .106,2 \\
8\end{array}$ & $467.109,96$ \\
\hline April & 3,6 & $\begin{array}{c}3.272 .860,7 \\
7\end{array}$ & $434.003,27$ \\
\hline May & 7,5 & 0 & $451.743,36$ \\
\hline June & 10,8 & 0 & $431.079,39$ \\
\hline July & 13,2 & 0 & $392.892,30$ \\
\hline August & 14,9 & 0 & $357.510,43$ \\
\hline September & 14,6 & 0 & $351.927,88$ \\
\hline October & 12,2 & 0 & $13.384,15$ \\
\hline November & 9 & $\begin{array}{c}2.659 .484,8 \\
7\end{array}$ & $392.542,92$ \\
\hline December & 6,1 & $\begin{array}{c}3.203 .693,7 \\
6\end{array}$ & $428.082,40$ \\
\hline
\end{tabular}

Table 4. The total consumption and cost of Natural gas for heating and hot water of residence

\begin{tabular}{|c|c|c|c|c|}
\hline Combi type & $\begin{array}{c}\text { Consumption } \\
\text { of N.gas for } \\
\text { heating } \\
\left(\mathrm{m}^{3} / \text { year) }\right.\end{array}$ & $\begin{array}{c}\text { Total N.gas } \\
\text { consumption } \\
\left(\mathrm{m}^{3} / \text { year) }\right.\end{array}$ & $\begin{array}{c}\text { Heating } \\
\text { cost } \\
\text { (TL/year) }\end{array}$ & $\begin{array}{c}\text { Total cost } \\
\text { (TL/year) }\end{array}$ \\
\hline $\begin{array}{c}\text { Conventional } \\
\text { combi }\end{array}$ & $2.325,59$ & $2.864,11$ & $2.372,11$ & $2.921,40$ \\
\hline $\begin{array}{c}\text { Condensing } \\
\text { combi }\end{array}$ & $1.962,49$ & $2.416,94$ & $2.001,74$ & $2.465,27$ \\
\hline
\end{tabular}

\section{Conclusion and Evaluation}

The pollution created by the waste gas for energy production, considering problems such as global warming and acid rain, fossil fuels are limiting the production of energy should be used efficiently. And to reduce the emission of greenhouse gases, increasing the use of alternative energy sources, reforestation and energy efficiency in the work needs to be done effectively. In this context planned by the Kyoto Protocol; taking the amount of greenhouse gases to 5\%, more fuel-efficient and much more taxing issue of carbon producing companies and organizations are thought to be important ingredients. In this study, compared to an average fuel consumption of the underlying apartment to meet the total energy needs of condensing the same power with an average fuel consumption of conventional boilers of the same power selected boiler at $15.6 \%$ compared to conventional combi condensing boiler has emerged that less fuel consumption. This difference is reflected in the $15.6 \%$ annual family costs 456 TL. The difference between the fuel consumption compared with the difference between the current price of condensing and conventional boilers, 1.5 years working to close the price gap is the efficient where the condensing boiler. When the estimated useful life of 15 years is considered boiler condensing boilers 13.5 years by providing more efficient working families an average of $15.6 \%$ total $6156 \mathrm{TL}$ savings will be increased to 3.6 times its price.

Combi boilers were sold in Turkey in 2010 is 754,996.0 units [5], this amounts to $10 \%$ of the condensing boiler is that with the adoption sold in 2010 is 679,496.0 Total amount of conventional boilers. The amount of the boiler equipped with older technology has completed its economic life in Turkey is thought to have about $3.500 .000,00$ units [2]. Here resulting from condensing boiler used in Turkey is emerging as economic losses annually 1,596,000,000.00 TL. In a sense, the cost of energy Turkey is annually leaving in the air is 1,596,000,000.00 TL Promoting condensing boilers in recovered energy and fuel saving is taken into the economic income account obtained consumers due to their positive contribution to the national economy and the environment informing the use of these systems should be integrated into national policy. Especially natural gas fired boiler and use of condensing technology in boilers should be mandatory, as in many EU member states. According to data provided by BOTAȘ in Turkey use of natural gas will be $59.5 \%$ in 2020 . Therefore, the use of natural gas in energy production in Turkey so intense promotion of condensing technology will contribute to the national economy in great extent.

\section{Symbols}

A Area of component $\left[\mathrm{m}^{2}\right]$

a Inward leakage flow $\left[\mathrm{m}^{3} / \mathrm{m} . \mathrm{h}\right]$

$c_{p} \quad$ Specific heat capacity of water $\left[\mathrm{J} / \mathrm{kg}{ }^{\circ} \mathrm{C}\right]$

$H \quad$ Values for different situation $\left[\mathrm{Wh} / \mathrm{m}^{3}{ }^{\circ} \mathrm{C}\right]$

$k \quad$ Heat transfer coefficient $\left[\mathrm{W} / \mathrm{m}^{2}{ }^{\circ} \mathrm{C}\right]$

$l \quad$ Lenght of leakage region $[\mathrm{m}]$

$m \quad$ Amount of water [kg/day]

$Q \quad$ Required energy for domestic hot water [W]

$Q \quad$ Overall heat loss of room [W]

$q_{i} \quad$ Incremental heat loss [W]

$q_{s} \quad$ Infiltration heat loss [W]

$q_{o} \quad$ Non-incremental heat loss [W]

$R \quad$ Special feature for room $[0,9]$

$T_{o} \quad$ Water outlet temperature $\left[{ }^{\circ} \mathrm{C}\right]$

$T_{i} \quad$ Water inlet temperature $\left[{ }^{\circ} \mathrm{C}\right]$

$Z_{D} \quad$ Unified incremental coefficient [\%]

$Z_{e} \quad$ Corner incremental coefficient [1]

$Z_{H} \quad$ Directional incremental coefficient [\%]

$\Delta T \quad$ Indoor and outdoor temperature difference $\left[{ }^{\circ} \mathrm{C}\right]$ 


\section{References}

[1] Anonim, World Energy Outlook 2010, International Energy Agency, Paris, 2010.

[2] Ertürk, F. U., Yoğuşmalı Kombi Teknolojilerinin Çevresel, Ekonomik Kazanımları Ve Yeni Hedefler, Yüksek Lisans Tezi, Trakya Üniversitesi, Edirne, 2010.

[3] Anonim, Climate Change 2013, Cambridge Unıversity Press, USA, 2013.

[4] Anonim, World Energy Investment Outlok, International Energy Agency, Paris, 2014.

[5] Bıyıkoğlu, A., Türkiye İklimlendirme Meclisi Sektör Raporu 2011, TOBB, Ankara, 2011.

[6] Omar, M.A., Altınışık, K., Reşitoğlu, İ.A., "Development of Semi-Spherical Porous Metal Matrix Burner for Combies", J. of Thermal Science and Technology, 35, 2, 137-143, 2015.

[7] Küçükçalı, R., Isıtma Tesisatı, Isısan Çalışmaları No: 265, İstanbul.

[8] Çevik, S., Enerji Verimliliği ve Türkiye'de Enerji Verimliliği Süreci, TTMD Dergisi 51, 26-33, 2007.

[9] Genceli, O. F., Parmaksızoğlu, İ. C., Kalorifer Tesisatı (7. Baskı), Makine Mühendisleri Odası, İstabnul, 2012 